\title{
農業用F AXデータ入カシステムにおける文字認識の手法
}

\author{
塩 光輝・町田 武美 \\ 茨城大学農学部， $=300-03$ 茨城県阿見町阿見中央
}

要 旨:

本システムで採用した文字認識法は，手書き数字の文字の形の特徴に注目して、文字の 方向と長さのベクトルを抽出し、さらにそれをパターン化して数字の同定を行う手法であ る.この方法によれば、短時間かつ小メモリーで数值文字の認識を行う事ができ，パソコ ンで行う処理に適している．また，文字認識の精度の面からも信頼できる手法であること が確認できた。

キーワード :

OCR，データ入力システム, 文字認識システム,ファクシミリ，F AXモデム

\section{1. はじめに}

本システムは一般的に利用されているファクシミリ機器（以下F A Xと呼ぶ）をOCR入力装 置として活用し , パソコンのソフトウェアで手書き文字を認識できるパーソナルな文字認識シス テムを開発したものである.

F A Xとパソコンを文字読みとりのシステムとして利用する場合には，処理速度や記憶容量な ど様々な問題が発生する．しかし、これらの諸問題も，文字読みとりの手法をいろいろ工夫する ことによって，十分に実用に供することのできるシステムとすることができる．

とくに処理速度に影響を与えるのは，どのような文字認識の手法を採用するかであり，パソコ ン・ソフトで文字認識を行えるための特有の方法を開発する必要がある. 交字識別の手法として は、パターン・マッチング法が一般的であるが、この他に数值の識別の場合には、ゾンデ法, 線 構造解析法、線図形化法、統計的方法など、様々な手法が提案されており，それぞれ一長一短が ある（安居院ら1986，木内1984）。

本論文の開発システムで採用されている数值の識別法は、これらのいずれの方法でもないユニー クな手法である. 本システムで採用したのは手書き数字の文字の形の特徵に注目して，交字の方 向と長さのベクトルを抽出し，さらにそれをパターン化して数字の同定を行う手法である. 本論 文ではこれを「ベクトル法」と呼んでいる。このべクトル法によれば。短時間かつ小メモリーで 数值文字の認識を行う事ができ，パソコンで行う処理に適している．また，手書き文字認識の精 度の面からも信頼できる手法である。

以下にベクトル法による文字認識の手法について，具体的な妈理結果を示しながら説明する. 
また、文字認識法として一般的なパターンマッチング法によ る処理結果も同時に示し, 本システムのベクトル法との比較 検討も行う。

\section{2. 文字認識の手法}

\section{1 文字認識の手順}

本システムで開発された文字認識部の作業の流れを示した のが図 1 である，パソコンで交字認識を行うため，メモリー と処理速度を考虑した特有の手法が用いられている。

始めに, 文字部の分離（切り出し）を行い,一定の座標範 囲から取り出された画像データの中から，必要な文字部分の みを抽出する作業を行う. 次に，文字のベクトル化を行う前 処理として, 文字の細線化と特徽の抽出を行う. 特徴抽出は 交字全体を認識の対象とするのではなく、数値文字に含まれ

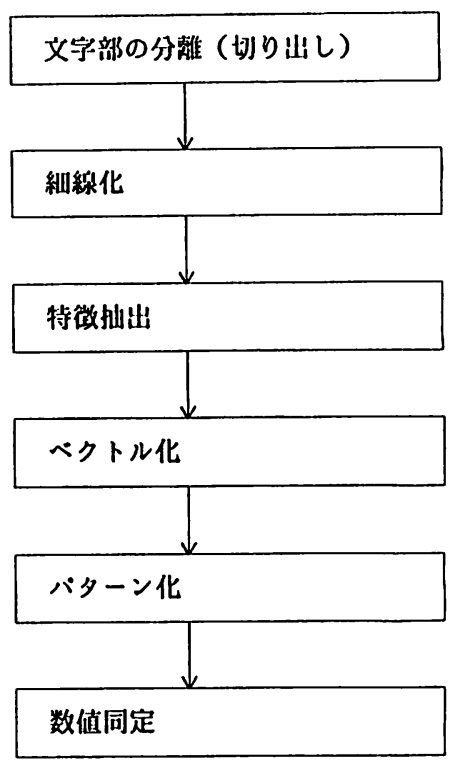

図 1 文字認識の手順 る数値固有の形状に着目して, 部分的な特徵を抽出する作業である.

こうして、一本の連続した線として把握された画像データから, 線の方向と長さのべクトルを 計算し，さらにそのベクトルの変化をパターン化して，最終的に数値の同定を行っている.

とくに本システムによる文字認識の特徴といえるのは, 手書きの数値の形に着目して、形の変 化をべクトル化し，それを A B Oのパターンに類型化する手法である. 本論交ではこれをべクト ル法と呼んでいる.

以下に文字認識の各手順毎にコンピュータ処理の方法を説明する.

\section{2 文字部の分離（切り出し）}

一定の座標範囲で原画像データから取り出された白黒のドットデータ（25×30のドットマ トリクス）には，交字そのもの以外にデータシートに記入されている枠線などの不必要なデータ も含まれており，これを始めに除去しておく必要がある．これが交字部の分離作業である.

図 2 に実例を示したが，この場合は，取り出した $25 \times 30$ のドットマトリクスの中に，「4」 という手書きの数值の他に, 左側と下方に外枠の線の一部が含まれている.

文字部の分離処理の基本的な考え方は，横方向（X方向）と縦方向（Y方向）それぞれについ て、黒のドット数の個数 (度数) を計算し，この度数分布が極小になる部分を分離点とする方法 である。

図 2 の場合のX方向ならびにY方向の度数分布を示したのが図 3 および図 4 である．この例で は， $\mathrm{X}$ 方向の度数分布は $\mathrm{X}=2$ と $\mathrm{X}=23$ の地点で極小となり，一方， $\mathrm{Y}$ 方向については $\mathrm{Y}=3$ 
とY=29で極小となっている. 従って、これらの極小地点までの周辺部領域を原画像データか ら削除する．以上の文字部の分離処理を施した結果が図 5 である.

また，文字によっては，極小点が現れないものや，極小点がいくつか存在する場合も生じる. 極小点がない場合は度数が急に増加する時点を、極小点が多い場合は、端点から 5 ドットの範囲 で最初に出現する極小点をそれぞれ分離点とする．

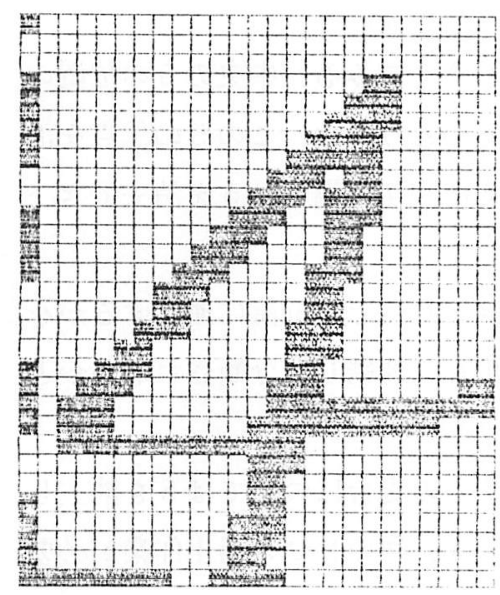

図 2 原画像データ

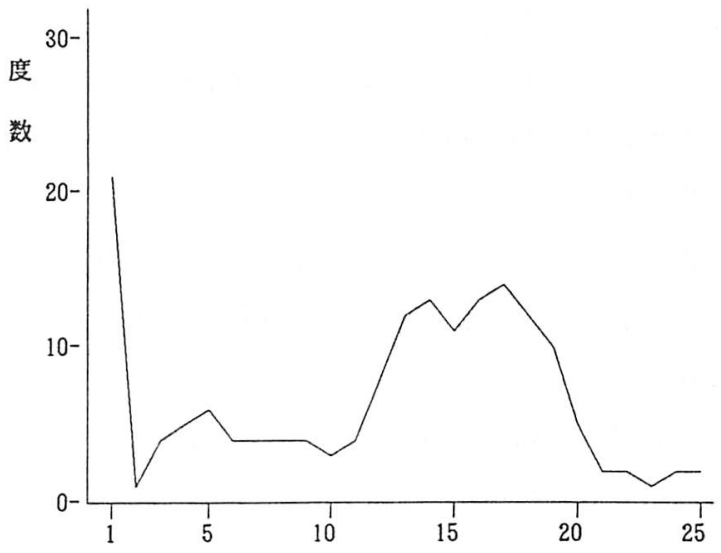

図 3 原画像のX方向の度数分布

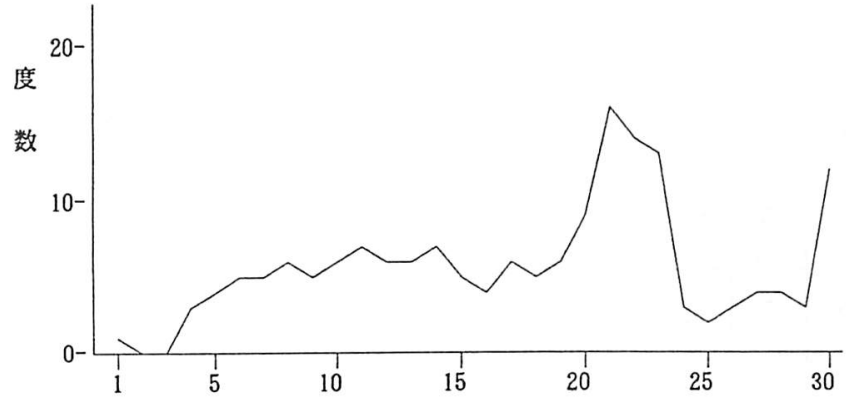

図 4 原画像の Y方向の度数分布

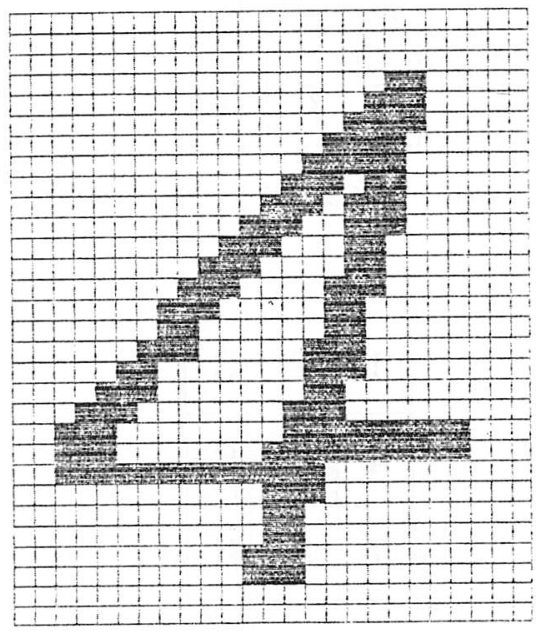

図 5 文字部の分離処理結果 


\section{3 細 線 化}

文字のベクトル化を行うためには文字が単一の線分で連続していることが条件となる．このた めの特殊な手法が、ここでいう細線化である。

一般にF A Xで入力された文字のドット表示を行うと, 図 2 や図 5 のように文字はある太さを もったドットの集合体として示される．このような太い線分を単一の線分に変換するためには， ドットの連続性を重視しながら不必要なドットの消去を行う必要がある.

いま図6に示されているような $3 \times 3$ のドットのマトリクスを考えてみる.中央の 5 の位置の ドットが黒点であるとき，このドットを消去して細線化ができるかどうかは，この 5 の黒点を消 去しても他の黒点が連結するかどうかの判定を行えばよい．例えば図 7 の場合は 5 を消去でき， 図8の場合は消去できない.

このような判定を行うには, 表 1 のように, 各番号のドット位置からどの位置に連結するかを あらかじめ决めておき，5のドットを除いても黒点のドットが相互に連結して分断されないかど うかを調べればよい。

ただし，交字の端点を保存するため，図 9 と図 10 のような 2 つの場合については 5 を消去し ないこととしなければならない。 また,この方式による細線化では，次の 2 つの補正作業が必要 である。

\begin{tabular}{|l|l|l|}
\hline 1 & 2 & 3 \\
\hline 4 & 5 & 6 \\
\hline 7 & 8 & 9 \\
\hline
\end{tabular}

図6 $3 \times 3$ のドットマトリクス

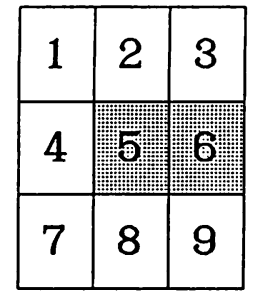

図 95 を消去できない場合 （連結点が 1 つのみ）

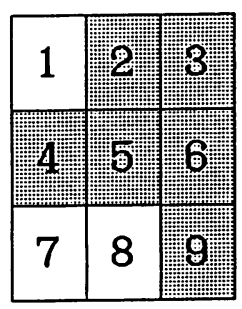

図 75 を消去できる場合

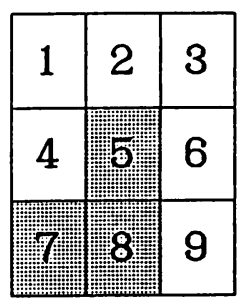

図10 5 を消去できない場合 （縦に長く、下部に 2 個 の連結点があるとき） 
農業用FAXデータ入カシステムにおける文字認識の手法

\section{1) 補正の 1}

連結する黒点の消去を実行すると，図 11 の ように中心部が空白で、周囲に黒点が残る場合 が生ずる．この上下左右の黒点の隣接部に連結 する黒点がない場合は，これらの黒点の一部は 不要であるため， 2 または $4 ， 6 ， 8$ の各黒点 を消去する補正作業を実行する。

\section{2 ) 補正の 2}

与えられたドットの集合について，上部から 連結する黒点の消去を実行すると，太い縦の線 の最下部においては図 12 のようなパターンが 出現する可能性がある，そこで, 最下部の場合 についてのみ、このような連続した横線の黒ドッ ト（図の 5 と 6 の各点）を消去する補正を行う. ただし， 1 が黒点の場合は，左側にも連結する 部分があるため, 消去は実施しない。

図 5 の事例について細線化を実施した結果を 図 13 に示しておいた.

\section{4 特徵抽出}

細線化された文字でも，これからただちに文 字のベクトル化を図ることは困難であり、ベク トル化の作業前に文字の特徵抽出を行わなけれ ばならない。

これは，例えば「4」という数值を考えてみ ると明瞭である。ベクトル化を図るということ は，とりもなおさず文字を一筆書きで書き表す ことと同一であり，文字の中にいくつもの分岐 線がある場合は，このままではべクトル化が困 難である、

$「 4 」$ 」場合, 頂部が分離して書かれているときは，最低 2 つのベクトルが生じ，単一のベク トルとして表示することができない，与えられた文字から分岐のない文字を抽出することは，文 字のもつ形の特徴を単純化させるだけでなく，交字の同定作業を容易にさせる.

表 1 各ドットから連結できるドットの番号

\begin{tabular}{|c|l|}
\hline ドット番号 & 連結するドット番号 \\
\hline 1 & 2,4 \\
2 & $1,3,4,6$ \\
3 & 2,6 \\
4 & $1,2,7,8$ \\
6 & $2,3,8,9$ \\
7 & 4,8 \\
8 & $4,6,7,8$ \\
9 & 6,8 \\
\hline
\end{tabular}

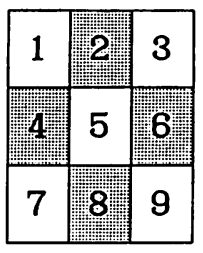

図11 周边黒点の消去

\begin{tabular}{|l|l|l|l|l|}
\hline 1 & 2 & 3 & 10 & $\begin{array}{l}\text { in } \\
11\end{array}$ \\
\hline 4 & 5 & 6 & 12 & 13 \\
\hline 7 & 8 & 9 & 14 & 15 \\
\hline
\end{tabular}

図12 最下部における 連続横線の消去

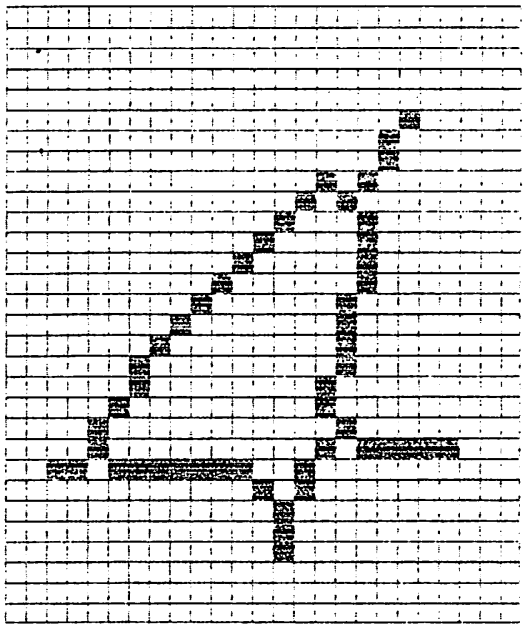

図13細線化の処理結果 
例えば前述の頂部が分離した「 4 」の場合、これを一筆書きで全て表すことはできないが、文 字の左側のみでよいと才れば、分岐のないベクトル表示が可能である。この場合、形は単純化さ れているが. 充分に「4」の形の特徴を残している.ベクトル化に先立ち、このような一筆書き で書き表すことのできるような文字の一部の抽出を、ここでは特幑抽出と呼ぶ.

特徵抽出を文字のどの部分から始めたらよいか（始点と呼ぶ）は重要な問題である. 始点は文 字の端点であることが望ましいが，「0」や「8」のように端点のない交字，あるいは「6」や

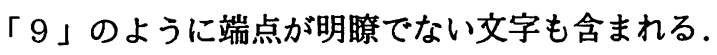

また，一般の人の筆順にならって，上部を始点と考えると，「4」や「7」あるいは「9」な どの場合，上部のどこを始点とするか判断に迷う．同じ文字でも文字の形状や傾きによって始点 が変わってしまう場合も考えられる.

そこで、このような文字の変化による影響を余り受けず、文字の特街をよくつかめるべクトル 化の始点で，かつ，統一的な考えで決定できる始点として，交字の最下端の右側（下右端）を始

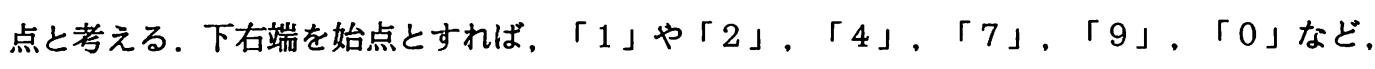
殆どの文字を統一的に取り扱うことが可能である.

また、このように明確に下右端そのものが始点とならない場合でも，下右端から左にトレース したときに端点が生ずるもの（「3」や「5」など）や，一度左側にトレースしたものを消去し， 次に右側にトレースしたときに端点が生ずるもの（「6」や「8」など）といった処理を行えば， 下右端から始点を見い出すことが可能である.

このような下右端でない始点の特銜としては次の 3 点があげられる.

(1)下右端から左または右へ連続線がある.

(2)トレースしたとき上端を通らない.

(3)トレースの終点（端点）が文字高さの $3 / 4$ より低い位置にある.

次に下右端からのトレースの方向も文字の特徴抽出では重要な問題である. 細線化を実施した 後でも文字には多くの分岐点が残されており,どの方向の分岐を優先させるか判断しなければな らない.

一般に文字の特徽を抽出するのに都合のよいトレース方向は、下右端からのトレースの場合. 上左側優先である。これには「4」、「5」、「6」、「7」、「8」、「9」、「0」といっ た殆どの文字が含まれる．これと別の方向（上右側優先） の方がよい場合が,「1」、「2」、「3」である.

このようにトレースすべき優先方向には 2 つの考え方 がある. しかし, 後者の上右側優先の場合でも, 分岐後 の距離の長い方をとることにすれば，上左側優先でも統 一的に扱うことができる．ただし，距離が短くても頂点 （上端）を通る場合はそれを優先させることにする.

(1)

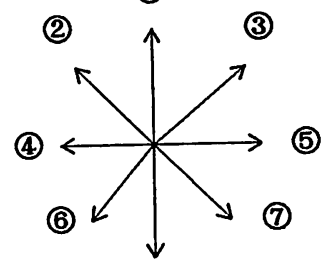

(8)

図14 トレースの優先方向 
以上の考察のまとめとして，まず，特徵抽出の始点は原則的に下右端とする．下右端から左右 に連続線がある場合は，トレースを行い，端点を始点とする．また，下右端から交字をトレース する方向は上左側を優先とし，優先順位は図 14 のようにとる．さらに分岐点があった場合は， その後の距離を計算し、距離の長い方を採用する.

なお，特徴抽出を行った文字を始点から終点へと向かう一つの線分とするため，文字の形状に よっては始点または終点を空白にする必要も生ずる．例えば図 15 に示されているような変形 $「 2 」 や 「 6 」 ， 「 8 」 の$ 場合は右側の端点を始点と考えるため始点を空白とする，一方「「0」 や「4」，「8」，「9」の場合は分岐後のトレースの結果, 分岐の開始点に戻ってしまうため, 終点を空白としなければならない.

図 15 に各種の手書き数值文字について，始点と終点の考え方の例を示しておいた．また，図 16 には特徴抽出を行う作業のフローチャートを，図 17 には特徵抽出の具体的な事例として, 図13の「4」の場合についての処理結果を示した.

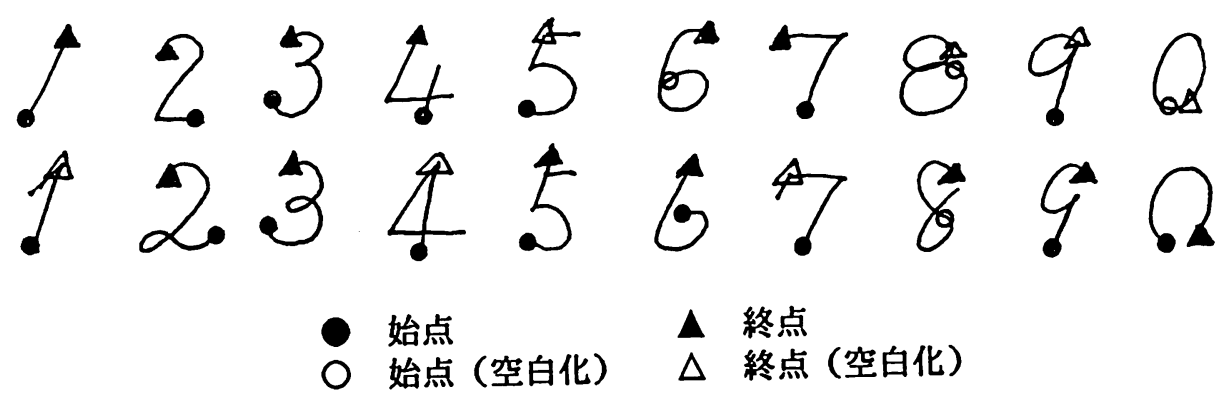

図15 文字の始点と終点 
農業情報研究 4(1), 1995.19-32

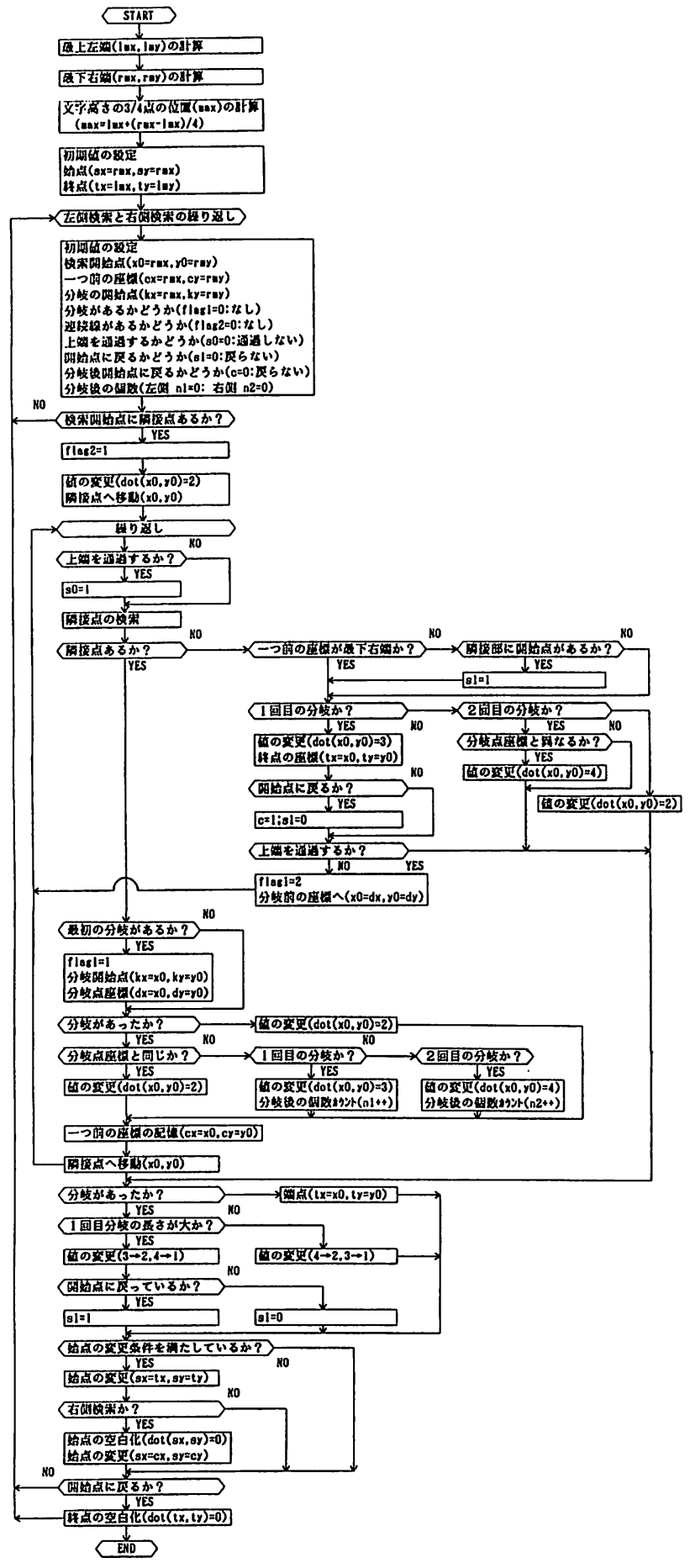

図16 特徽抽出のフローチャート 


\section{5 ベクトル化}

前述した特徴抽出によって，文字は分岐のな い単一の連続線として表示される．この文字を 構成するドットを始点から終点までトレースし， そのベクトル（長さと方向）を記録するのが. ここでいうべクトル化の作業である.

まず、ベクトルの方向は，図 18 のような時 計回りの方向へ 1 から 8 までの数值で表す. 次. に 1 つのドットについて，前のベクトルと次の ベクトルとの差を計算する. ベクトルの差は図 19 のように, 同一方向の場合を 0 , 右へ 45 度方向が変化するときを+ 1 , 左へ 45 度変 化するときをー 1 とする．向きが全く逆にな ることはない.

このようにして得られたベクトルの差の值 全体について平準化を行う. 平準化を行う前 の值は極端なでこぼこが生ずる可能性が高い ので、隣接 3 点の平均値をとる平準化が必要 である。

\section{6 パターン化による数値認識}

まず、ベクトル化した方向值の平準化を 2 回行い, さらにその数值の累積計算を行う. そして, 得られた累積ベクトル值を 6 分割し、 数值の変化から A B Oの 3 つのパターンに分 類する.

分割数をあまり大きくすると、ベクトル変 化が細かすぎて文字の全体としての特徴がつ かまえにくくなり，逆に分割数が少なすぎる と文字のベクトル変化の特徴が分加らなな る. 試行錯誤の結果, 6 分割が最も妥当であ るという結論に達した。

ここでA B Oは，次のように文字の方向性

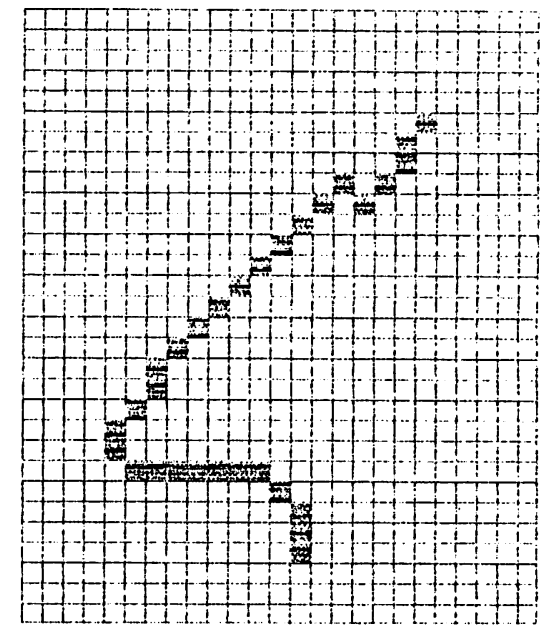

図17 特徴抽出の処理結果

(1)

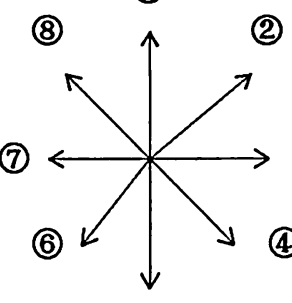

(5)

図18 ベクトルの方向

図19 ベクトルの差

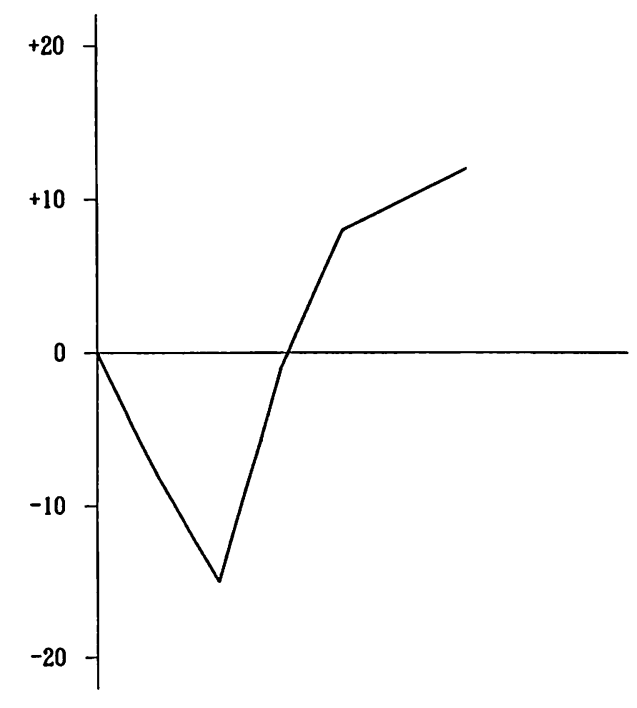

図20 累積ベクトル 
を表す指標である.

[A] : 時計回りの方向

[B] : 反時計回りの方向

[O ] : 直線方向

例えば「7」という文字は、はじめに直線部（O）があり, 次に反時計回りの部分（B）があ るため, 基本パターンは $[\mathrm{OB}]$ となる.また、3の場合は、はじめに反時計回り（B），次に 時計回り（A），そして最後にまた反時計回りがあるため, 基本形は [B A B ] となる.

具体的な事例として，図 17 の場合の累積ベクトルを示したのが図 20 である。この結果から パターン化を行うと，パターンB A Oとなり，数字は「4」であると同定される.

このような基本形の他に，文字の微妙な形の変化に応じて多数の発展形が生じる. 表 2 に各数 值文字の基本形と発展形のパターン一覧を示した.

こうした A B Oのパターン化によって，基本的に数值文字の同定が可能である．しかし，手書 き文字の場合、別個の数字でも類似したパターンとなるものが出現する. 例えば表 2 にも示され ているように、「9」の基本形O B A と、「4」の発展形のパターンは重複している.

そこで、このように重複しているパターンでも文字の同定が行えるよう，次の 2 つの作業を補 足的に実行して差別化を行っている.

$1 ） 6$ 分割された累積ベクトル值の傾向による区別

例えばパターンB A B では，最終数值が正のものを 0 と判別し，最終数值が負の場合は「3」 と判別する．また，パターンがAＯBの場合は，最終数值が正のものは「 $2 」 ，$ 負のものは「 $7 」$ である。

2 ）特徴抽出における未使用部による区別

前述したように，特徵抽出では与えられた文字の中から特徽的な線分のみを抽出しているため， 抽出されなかった部分は文字の同定に使用されていない．この未使用部の文字がどのような範囲 に分布しているかによって，文字の区別を行う手法である.

例えば「3」では，中央部に未使用文字が残されている場合があり，「5」では上部に横線が 残されている可能性が高い。また「年」では中央部に縦線が残されている. 
表 2 数值とパターンの関連表

\begin{tabular}{|c|c|c|c|}
\hline 数值 & 基本形 & 発展形 & 特殊形 \\
\hline 0 & $\mathrm{~A}$ & $O A, A O A$ & BAB \\
\hline 1 & 0 & & \\
\hline 2 & $\begin{array}{l}\mathrm{OAB} \\
\mathrm{AB}\end{array}$ & $\begin{array}{l}\text { OAOB, OBOB } \\
\text { AOB }\end{array}$ & \\
\hline 3 & B A B & OBOAB, OBAB, $\mathrm{BOB}, \mathrm{BAO}$ & \\
\hline 4 & $\begin{array}{l}\text { OBAO } \\
\text { OAO }\end{array}$ & $\begin{array}{l}\text { OBOAO, OBA, BAO, BAOAB } \\
\text { BOAO }\end{array}$ & \\
\hline 5 & $\begin{array}{l}\mathrm{BO} \\
\mathrm{B} \mathrm{A}\end{array}$ & $\begin{array}{l}\text { OBO } \\
\text { BOA, BOAO, OBOA, OBAO, BAO }\end{array}$ & \\
\hline 6 & $\mathrm{AO}$ & & $\mathrm{ABO}$ \\
\hline 7 & OB & & $\mathrm{AOB}$ \\
\hline 8 & $\overline{A B A}$ & $\mathrm{ABOA}$ & \\
\hline 9 & $\mathrm{OBA}$ & & \\
\hline
\end{tabular}

\section{3. パターンマンチング法との比較}

以上が本システムで採用されている文字認識手法の具体的な手順であり，本論文ではこれをべ クトル法と呼んでいる．このベクトル法の有用性を検証するため.文字認識の一般的手法として 良く知られているパターンマッチング法との比較検討を行った.

比較検討の対象としたのは、いわゆる単純パターンマッチング法（安居院ら1986, 尾上1987） である．F AXによって読みとられた $25 \times 30$ ドットの原画像に対し，一度，文字部の分離処 理（切り出し作業）を施し、これを既に同定されている他の基本画像との重ね合わせによってマッ チングを行う方法である。

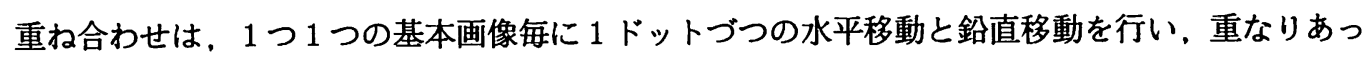
た黒ドットの比率（重復度と呼ぶ）が最も高いもの（最大重複度のもの）を同定の対象とした. 重ね合わせの対象とする基本画像は，1つの数值について20種類用意した. 従って0〜9 までの 数值全体については, 合計 200 種類のパターンとの比較を 1 つの画像について実施することにな る.

また，重複度は次のような計算式によった．重複度は完全にパターンが一致するとき 2 である.

重複度 $\mathrm{OV}=\mathrm{SO} / \mathrm{SI}+\mathrm{SO} / \mathrm{S} 2$

ここに, SO : 重なった黒ドットの個数

$\mathrm{S} 1$ : 比較する基本画像の黒ドットの総数

$\mathrm{S} 2$ : 比較される 
200種類の手書き数字についてパターンマッチング法による検討結果を示したのが表 3 である. 正答率は文字の種類によって変動があり，最高で85\%（「1」と「2」），最低で20\%（「4」）， 全体では60\% という結果となった．また，誤った同定結果となった文字では，誴答の原因となっ た他の類似する数字に一定の傾向が見られ，例えば正答率の低い「4」では「 $1 」 と 「 9 」 に$ 判 定されたものが多く，全体として「1」が多いのが特徴である.

表 3 パターンマッチング法による同定結果

\begin{tabular}{|c|c|c|l|l|}
\hline 数值 & 正答の最大重複度 & 誤答の最大重複度 & 正答率 & 誤答の多い数值 \\
\hline 0 & $1.621 \sim 1.201$ & $1.480 \sim 1.126$ & 0.650 & 6,1 \\
1 & $1.786 \sim 1.230$ & $1.413 \sim 1.354$ & 0.850 & \\
2 & $1.757 \sim 1.125$ & $1.206 \sim 1.080$ & 0.850 & \\
3 & $1.572 \sim 1.000$ & $1.421 \sim 0.926$ & 0.700 & 2 \\
4 & $1.427 \sim 1.234$ & $1.495 \sim 1.164$ & 0.200 & 1,9 \\
5 & $1.253 \sim 1.133$ & $1.413 \sim 1.150$ & 0.400 & 1,6 \\
6 & $1.552 \sim 1.238$ & $1.480 \sim 1.161$ & 0.400 & 0,1 \\
7 & $1.481 \sim 1.219$ & $1.432 \sim 1.308$ & 0.800 & 1 \\
8 & $1.405 \sim 1.175$ & $1.368 \sim 1.099$ & 0.650 & \\
9 & $1.521 \sim 1.210$ & $1.495 \sim 1.138$ & 0.500 & 1 \\
全体 & $1.786 \sim 1.000$ & $1.495 \sim 0.926$ & 0.600 & \\
\hline
\end{tabular}

誤答の最大重複度の範囲から判断すると，同定の精度を上げるためには最低1.500の最大重複 度が求められている．しかし，最大重複度を1.500に引き上げて判定するとすれば，同定できな い文字も増加し、結果として正答率が低下することも考えられる。

なお、この方法による同定の速度は，1つの画像について（200種の基本画像との比較で）平 均 1 分 28 秒を所要した.

このように，文字部の分離処理（切り出し）のみを施した原画像の単純なパターンマッチング では，同定の精度が悪く，また処理時間も過大となることが判明した．1つの文字で 1 分 28 秒 を要するということは，約 100 個のデータを含む 1 頁分のデータシートの判読に約 2 時間半の 時間がかかることになり、これでは殆ど実用に供さない。

これに対して，本論文で採用したべクトル法によれば，F A Xからのデータシートの入力時間 を含めても，手書きの数字とチェックマーク合計 115 個を認識するのに約 2 分で全ての処理を 終了することが可能である.

もし，パターンマッチング法を採用する場合には，単純な比較ではなく，文字の正規化などを 行うための様々な処理手順を付加することや，基本画像の種類を増やすことなどが必要となり， さらに交字認識時間が増加することが考えられる，そして，処理時間を短縮するためには，専用 の画像認識を行うハードウェア的処理や，大型コンピュータでの処理が求められ，もはやパソコ ン・ソフトで行うパーソナルな画像認識の範瞦では処理できない課題となる. 


\section{4. 考察}

本論文では F A Xとパソコンによる個人レベルでも利用できる文字認識システムを開発し、具 体的な文字認識の手法とその処理結果の説明を行った．また，文字認識法として一般的なパター ンマッチング法による処理結果との比較検討も行った。

本システムで採用した文字認識法は、認識すべき文字の種類を数值とチェックマークに限定し， 手書き数字の場合は文字の形の特徵に注目して，交字の方向と長さのベクトルを抽出し，さらに それをパターン化して数字の同定を行う手法である. 本論文ではこれ「ベクトル法」と呼んでい る.

このベクトル法によれば，短時間かつ小メモリーで数值文字の認識を行うことができ，パソコ ンで行う処理に適している．また，文字認識の精度の面からも信頼できる手法であることが確認 できた。

このようなべクトル法による文字認識を行うことによって，F AXとパソコンでも充分に文字 認識を行うことが可能である．運用結果では，A 4版のデータシート上に記入された手書きのデー 夕（数值とチェックマークを含む）115個を認識するのに、システムの開始時点から約 2 分間で 全ての文字認識を終了した，また，現在までの実験結果では，文字認識の正確さはほぼ $90 \%$ \%て ある。

認識に失敗した数值は，手書き文字の一部に断点があり，一筆書きで表示されなかったもので ある. 即ち、これらの文字は手書きの途中でかすれていたものであり、べクトル法のみによる文 字認識手法の限界を示しているとも考えられる。

今後の課題としては、テストデータを増やして文字認識の精度を向上させ，さらに実用に臫え うるシステムとしての改善を行うこと，他の認識手法と併用して文字認識の精度を向上させるこ と、文字認識の全体の処理速度を向上させること、さらに、認識できる文字の種類を増やすこと などが考えられる.

また、このような F AXとパソコンによる文字認識システムを利用した。さまざまな農業支援 ソフトへの応用も今後の課題である.

\section{引用文 献}

1)安居院猛・ 中嶋正之(1986)画像工学の基礎. 昭晃堂:123-147.

2)木内雄二(1984) 画像認識のはなし.日刊工業新聞社: 85-141.

3)尾上守夫(1987) 画像処理ハンドブック.昭晃堂:148-174. 


\section{On the Method of Character Recognition in a Data Inputting System by Using a Facsimile as OCR}

\section{Kohki Shio and Takemi Machida}

Faculty of Agriculture, Ibaraki University

Cyuou, Ami, Ibaraki 300-03, JAPAN

\section{Summary}

The authors have developed a character reading system by using a facsimile, and a method of character recognition which is applied in this system and some executed results are explained in this paper, including a comparison analysis of a general recognition method which is popular as the Patttern Matching Method.

The applied method in this paper is called Vector Method which is characterized by making characterization of the figures of handwritten numerals, and after processing directions and lengths of a character and making pattern classification, the numeric character can be recognized. By using the Vector Method one can recognize numeric characters not only in a short time but also with a small computer memory. A data-sheet with 115 handwritten data can be processed within 2 minutes and the validity of character recognition is about $90 \%$ at pesent.

Therefore it can be concluded that this method is appropriate to the character recognition system for personal computers.

A flow chart of the character recognition procedure is shown in Fig.1 and by way of example, image processing results are shown from Fig. 2 to Fig.5. Fig.13 and Fig.17. 